\title{
Effect of Vitamin A Supplementation on Performance and Blood Constituents of Saidi Ewes and Their Offspring Q
}

\author{
Soliman, I.A.; M.N.M. Abd El-Ati; G.B.A. Mahmoud and Zeinab M.M. Hassan
}

Department of Animal Production, Faculty of Agriculture, Assiut University, Egypt

Received on: 10/4/2019

Accepted for publication on: 22/4/2019

\section{Abstract}

Forty pregnant ewes of more than two successive lambing seasons, at the second half of gestation period, were used to evaluate the effects of supplemented vitamin A on growth performance, blood constituents, levels of vitamin $A$ and $\beta \square$ carotene of Saidi ewes and their offspring. Pregnant ewes $(48.48 \pm 0.09 \mathrm{~kg} \mathrm{~B}$. W.) were assigned to 4 treatment groups of 10 ewes each in the Farm of Animal Production Department, the Faculty of Agriculture, Assiut University, Assiut, Egypt.. Vitamin A was drenched in the form of pale yellow to brown granular powder as vitamin A acetate content $\geq$ $1,000,000 \mathrm{IU} / \mathrm{g}$ which had been certified by china council for the promotion of international trade. In group I both ewes and lambs were not treated. In group II ewes were not treated while lambs were given 10,000 I.U. In group III ewes were given 150,000 I.U. of vitamin A /head fortnightly while lambs were not treated. In group IV ewes were given 150,000 I.U. of vitamin A /head while lambs were given 10,000 I.U fortnightly. Feeds were offered once daily and fresh tap water was free available allover the day. Ewes were housed in semi open pens under the normal environmental conditions. Before feeding and drinking, ewes were weighed fortnightly throughout the experimental period. Lambs were weighed at birth and then weighed fortnightly throughout the experiment. Blood was obtained every 14 days to evaluate blood constituents in blood serum of ewes and offspring.

In general, body weight and daily weight gain in ewes and offspring improved ( $>0.05)$ by supplemented vitamin A. However, blood profiles were not affected by vitamin A supplementation, except mean of platelets volume (MPV) levels were higher $(\mathrm{P}<0.05)$ in treated ewes (group IV), while number neutrophils was lower $(\mathrm{p}<0.05)$ in untreated lambs (group I) compared with other ones. Concentrations of total protein and globulin were higher $(\mathrm{p}<0.05)$ in blood serum of untreated ewes (group I ), while albumin / globulin ratio were higher $(\mathrm{p}<0.05)$ in group IV , but levels of albumin reduced $(\mathrm{P}<0.05)$ in blood serum of group III compared with other groups. Concentration of total cholesterol increased $(\mathrm{p}<0.05)$ in blood serum of group IV compared with other ones. Concentrations of glucose, triglycerides and urea in blood serum were not different $(\mathrm{P}>0.05)$ among treatments. Vitamin $\mathrm{A}$ and $\beta \square$ carotene levels in blood serum of ewes were not different significantly among treatments, while Vitamin A concentration was higher $(\mathrm{P}<0.05)$ for lambs in group II and IV of ages 30 and 60 days than other groups. In conclusion, addition vitamin A improved body performance of ewes and their offspring without any harmful effecton blood constituents.

\section{Keywords: Vitamin A, saidi ewes, lambs, blood constituents.}

\section{Introduction}

It is regarded that vitamin $\mathrm{A}$ protects cells from damage by radicals which are believed to contribute to certain chronic diseases and regulates immune function of animals by protection of mucosal epithelium acting as the first defense barrier (Kamiloglu et al., 2006). All these properties of vitamin A may be attributable to its antioxidant activity (Yang et al., 2010). Vitamin $\mathrm{A}$ is 
generally supplemented to ruminant especially to those confined to insure their optimum health and maximum productivity (Alosilla et al., 2007). Administration of vitamins has been known to alleviate negative effects of harsh conditions and to improve animal productivity (West, 1997; Marai et al., 2008). However, it has been reported that as much as $80 \%$ of the vitamin A supplemented were degraded in the rumen after ingestion and the ruminal degradation of vitamin A was in a diet dependent manner, being higher for concentrate than for forage diet (Rode et al., 1990; Alosilla et al., 2007). Vitamin A, because of its essential role in metabolism of epithelial tissues, might be required in greater amounts by lactatings (Swanson et al., 1986). In early lactation, the ewe's nutrient requirements increase dramatically, particularly for ewes nursing twin or triplet lambs (Pope et al., 1949). Supplementation of carotene to ruminant during lactation was essential for normal vitamin A nutrition regardless of whether the animals had low or high liver vitamin A stores at parturition (Meacham et al., 1970).

This study was to evaluate the effects of supplemented vitamin A on growth performance, blood constituents and levels of vitamin A and $\beta \square$ carotene of Saidi ewes and their offspring.

\section{Materials and Methods}

This study was conducted in the Farm of Animal Production Department, the Faculty of Agriculture, Assiut University, Assiut, Egypt. The aim of this research was to evaluate the impact of vitamin A supplementation to the diets of Saidi ewes and their offspring on body weight, hemato-biochemical analysis and levels of vitamin $A$ and $\beta \square$ carotene in blood serum of the experimental animals.

\section{Treatment of animals:}

Forty ewes of more than two successive lambing seasons, at the second half of gestation period, were used to in this experiment. Pregnant ewes $(48.48 \pm 0.09 \mathrm{~kg} \mathrm{~B}$. W.) and were assigned to 4 treatment groups of 10 ewes each. Vitamin A was drenched before feeding in the form of pale yellow to brown granular powder as vitamin A acetate content $\geq 1,000,000 \mathrm{IU} / \mathrm{g}$ which had been certified by china council for the promotion of international trade (2016). In group I both ewes and lambs were not treated. In group II ewes were not treated while lambs were given $10,000 \mathrm{I} . \mathrm{U} / \mathrm{head}$ fortnightly. In group III ewes were given 150,000 I.U. of vitamin A /head fortnightly while lambs were not treated. In group IV ewes were given 150,000 I.U. of vitamin A /head fortnightly while lambs were given 10,000 I.U/head fortnightly. Feeds were offered once daily and fresh tap water was free available all over the day. Ewes were housed in semi open pens under the normal environmental conditions. Before feeding and drinking, ewes were weighed fortnightly throughout the experimental period. Lambs were weighed at birth and then weighed fortnightly throughout the experiment. Pregnant ewes daily ration was composed of $50 \%$ yellow corn, $17 \%$ soya bean, $30 \%$ wheat bran $2 \%$ limestone and $1 \%$ sodium chloride.

\section{Collection of blood samples:}


Blood samples were taken at the beginning of the experiment and then fortnightly before morning feeding from each ewe and offspring via jugular vein puncture into $5-\mathrm{mL}$ tube (non-heparinized) and $2 \mathrm{~mL}$ tube (containing anticoagulant) vacuum tubes. The blood samples in $5-\mathrm{mL}$ tube were incubated at $37^{\circ} \mathrm{C}$ for $2 \mathrm{~h}$, subsequently centrifuged at $2,500 \times$ $\mathrm{g}$ for $10 \mathrm{~min}$ and the serum was stored at $-20^{\circ} \mathrm{C}$ for analyses of selected blood metabolites, Vitamin A and $\beta \square$ carotene. The blood samples in $2 \mathrm{~mL}$ tube were used for routine analysis of blood profiles.

\section{Statistical analyses:}

All data were statistically analyzed as completely randomized designs by one-way ANOVA using GLM model of SAS (2000) with vitamin A level as main effect and individual animal as statistical unit. For analysis of blood cells and metabolites. Duncan's multiple range test was used todetermine significant differences between treatmentmeans. The efficacy of supplemental vitamin A wasdetermined by using a contrast between control andadditives. Difference was declared at $\mathrm{p}<0.05$.

\section{Results and Discussion}

Effect of vitamin A on growth performance of ewes and its offspring:
Vitamin A is routinely supplemented to ruminant diets to insure maximum health and productivity (Alosilla et al., 2007). Data in Tables (1 and 2), averages of body weight and daily gain of ewes and their offspring treated with vitamin A. Initial body weight in ewes and lambs were the same in all treatments. Treated ewes and offspring did not influence by supplementing vitamin A. However, final body weight of ewes in TC and TT groups improved $(\mathrm{P}>0.05)$ compared with other treatments, while final body weight in TT treated lambs was higher insignificantly compared with other experimental groups. These results are in agreement with those reported by Yang et al., (2010) that feed intake and feed efficiency were not affected by vitamin A supplemented at the level of 2000,3000 or $5000 \mathrm{IU} \mathrm{kg}-1 \mathrm{DM}$ in the diets of lactating ewes.

Oka et al. (1998) demonstrated that no linear or quadratic effects of vitamin A levels on live weight gain, feed intake, or feed efficiency when goat fed high or low vitamin A diets. In general, body weight and daily weight gain in ewes and their offspring slightly improved ( $>0.05)$ by supplemented vitamin A.

Table 1. Averages values of body weight (Kg) and daily gain (g) of ewes supplemented with vitamin $A$.

\begin{tabular}{|l|r|r|r|r|}
\hline \multicolumn{1}{|l|}{ Groups Items } & Group 1(CC) & Group 2(CT) & Group 3(TC) & Group 4(TT) \\
\hline \multirow{2}{*}{ Initial Weight(kg) } & $49.53 \pm 2.33$ & $48.64 \pm 2.72$ & $48.71 \pm 2.52$ & $48.87 \pm 2.52$ \\
\cline { 2 - 5 } & \multicolumn{5}{|c|}{ N.S } \\
\hline \multirow{2}{*}{ Final Weight(kg) } & $53.60 \pm 2.32$ & $52.93 \pm 2.97$ & $55.54 \pm 2.02$ & $55.49 \pm 2.97$ \\
\cline { 2 - 5 } & $117.99 \pm 16.60$ & $127.67 \pm 27.17$ & $167.35 \pm 21.67$ & $151.13 \pm 20.55$ \\
\hline \multirow{2}{*}{ Daily gain (g) }
\end{tabular}


CC: Control animals, CT : Ewes untreated while offspring treated with 10.000IU of vitamin A. TC : Ewes treated with 15.000 IU vitamin A with offspring not treated. TT : Ewes and their offspring were treated with vitamin A.

Table 2. Averages values of body weight (Kg) and daily gain of offspring (g) supplemented with vitamin $A$.

\begin{tabular}{|l|r|r|r|r|}
\hline Groups Items & Group 1(CC) & Group 2(CT) & Group 3(TC) & Group 4(TT) \\
\hline \multirow{2}{*}{ Birth Weight(kg) } & $3.00 \pm 0.03$ & $2.84 \pm 0.18$ & $3.56 \pm 0.14$ & $3.27 \pm 0.24$ \\
\cline { 2 - 5 } & \multicolumn{4}{|c|}{ N.S } \\
\cline { 2 - 5 } Final Weight(kg) & $9.09 \pm 0.57$ & $8.36 \pm 1.00$ & $10.43 \pm 1.67$ & $10.94 \pm 1.75$ \\
\hline \multirow{2}{*}{ Daily gain (g) } & $43.56 \pm 3.85$ & $53.73 \pm 9.16$ & $43.56 \pm 3.85$ & $63.67 \pm 7.54$ \\
\cline { 2 - 6 }
\end{tabular}

.CC: Control animals, CT : Ewes untreated while offspring treated with 10.000IU of vitamin A. TC : Ewes treated with $15.000 \mathrm{IU}$ vitamin A with offspring not treated. TT : Ewes and their offspring were treated with vitamin A.

2. Concentrations of $\beta \square$ carotene and vitamin $A$ in blood serum of ewes and their offspring:

$\beta \square$ carotene and Vitamin A levels in blood serum of ewes did not different significantly among treatments (Table 3) but differed highly significant between periods, while Vitamin A concentration was higher significantly $(\mathrm{P}<0.01)$ for ewes in treatments III and IV, as well as for lambs $(\mathrm{P}<0.05)$ in periods 2 and 3 compared with other groups. Regardless the treatments, concentrations of $\beta \square$ carotene increased $(\mathrm{P}>0.05)$ insignificantly, while levels of Vitamin A increased $(\mathrm{P}<0.05)$ significantly at age 30 and 60 in lambs than other groups (Table 4). Liver is the primary storagesite for Vitamin A and serum level of retinol was used as an indicator of Vitamin A status in the liver (Oka et al., 1998 and Carrillo-Lopez et al., 2010). It is regarded that vitamin A intake is necessary to maintain the optimal level of vitamin A in blood (May, 1982).

Table 3. Means and standard error of $\beta \square$ carotene and vitamin $A$ in blood serum of ewes supplemented vitamin $A$ as affected by treatments and ages.

\begin{tabular}{|c|c|c|}
\hline \multicolumn{1}{|c|}{ Treatment } & $\boldsymbol{\beta} \square$ carotene (N.S.) & Vitamin A (**) \\
\hline Group 1 CC & $5.53 \pm 0.71$ & $74.32^{\mathrm{b}} \pm 5.67$ \\
\hline Group 2 CT & $5.39 \pm 0.85$ & $89.66^{\mathrm{a}} \pm 5.92$ \\
\hline Group 3 TC & $6.91 \pm 1.20$ & $90.00^{\mathrm{a}} \pm 5.08$ \\
\hline Group 4 TT & $5.74 \pm 0.51$ & $94.19^{\mathrm{a}} \pm 5.65$ \\
\hline Period & $* *$ & $* *$ \\
\hline $\mathbf{1}$ & $4.18^{\mathrm{b}} \pm 0.59$ & $85.66^{\mathrm{b}} \pm 5.65$ \\
\hline $\mathbf{2}$ & $8.31^{\mathrm{a}} \pm 0.72$ & $99.49^{\mathrm{a}} \pm 2.68$ \\
\hline $\mathbf{3}$ & $5.46^{\mathrm{b}} \pm 0.66$ & $75.98^{\mathrm{b}} \pm 5.27$ \\
\hline
\end{tabular}

$\mathrm{a}$, b: Means within a row containing different superscript tended to differ $(\mathrm{p}<0.05)$; $\mathrm{c}$ : SEM $=$ Standard Error of the Mean.CC: Control animals, CT : Ewes untreated while offspring treated with 10.000IU of vitamin A. TC : Ewes treated with 15.000 IU Vitamin A with offspring not treated. TT : Ewes and their offspring were treated with vitamin A 
Yang et al., (2010) reported that, supplementation of Vitamin A at the level up to $5000 \mathrm{IU} \mathrm{kg-1} \mathrm{DM} \mathrm{in-}$ creased retinol concentration in the serum both linear $(\mathrm{p}<0.01)$ and quadratic $(p<0.01)$. They showed that ewes supplemented with vitamin A at the level of $5000 \mathrm{IU} \mathrm{kg}-1$ had higher serum concentration of retinol than control ewes. Several other authors studies (Chew, 1996; Alosilla, 2007; Arana et al., 2008) agreed that dietary supplementation of Vitamin A increased retinol level in the serum of lambs and cattle. This information indicated that as the supplementation level increasing greater amount of Vitamin A escaped the ruminal degradation and absorbed in the small intestine to exert its antioxidant effect on animal physiology.

\section{Hemato-biochemical parameters} of ewes and their offspring :

\subsection{Blood profiles of ewes and their offspring:}

Effect of Vitamin A supplementation on blood profiles of experimental ewes and their offspring is shown in Table 5 and 6. Blood profiles of treated ewes and its offspring did not influence by dietary Vitamin A in the diets, except the levels of neutrophils percent increased $(\mathrm{P}<0.05)$ in blood of ewes (group 2) as compared with other groups, while the levels of mean platelets volume (MPV) was higher $(\mathrm{P}<0.05)$ in blood of group 4 than other groups. In the same field, number of neutrophils decreased $(\mathrm{P}<0.05)$ in blood of treated offspring compared with control ones.

Yang et al., (2010) illustrated that Red blood cells in blood of lactating ewes showed both linear $(p<0.01)$ and quadratic $(p<0.01)$ in- creases in response to the dietary additions of vitamin A. The level of 3000 IU kg-1 Vitamin A supplementation had greater $(\mathrm{p}<0.05)$ lymphocyte, hemoglobin and haematocrit than the control group and other test groups. Red blood cells were significantly increased $(p<0.05)$ by the tested groups. An increase in blood neutrophils is regarded as the first line of defense associated with clinical and subclinical infection (Vander Peet-Schwering et al., 2007).

Lymphocytes were increased by the supplementation of Vitamin A, indicating that Vitamin A improved the immune function of lactating ewe in this study. Lin et al. (2002) suggested that Vitamin A plays a role in modulating immune system and low vitamin A status has been reported to result in a reduction of cell mediated immune responses and decreased specific antibody responses following immunization (Bendich, 1993). All these results suggestd that supplementation of Vitamin A in lactating ewe may have potential in enhancing immuno-system. The mechanism by which Vitamin A modulates immunity is not clear, but may partly due to the antioxidant activity of Vitamin A. It has been regarded that improving antioxidant status enhanced immune function of animals (Grimble, 2001).

Also, Vitamin A has been known to have a role in hematopoiesis (Sporn et al., 1994) and immunity functions (De et al., 2014). On the other hand, values of MCV (mean cell diameters) and $\mathrm{MCH}$ were adversely affected by supplementing of Vitamin A as reported by Hashem et al. (2016). This may be due to an increase in bio-synthesis rate of eryth- 
rocytes from bone marrow resulted in formation of red blood cells with lower diameters (MCV) and thus lower hemoglobin content $(\mathrm{MCH})$ but without affecting the percentage of hemoglobin inside erythrocyte (MCHC).

Reported that supplementation rate with Vitamin $A$ or $\beta$-carotene protected its immune responses to certain environmental sources of free radicals. Vitamin A can function as natural antioxidants to remove harm- ful free radicals produced through normal cellular activity and from environmental stressors, thereby maintaining the structural integrity of immune cells (Chew, 1996). The improved antioxidant status together with the enhance immune function by supplementation of Vitamin A observed in this study indicated that $\mathrm{Vi}$ tamin A may serve as an antioxidant to protect the immune cells against oxidant stressors and thereby maintain optimum immune function.

Table 5. Concentrations of blood profiles of ewes supplemented Vitamin A.

\begin{tabular}{|c|c|c|c|c|}
\hline Groups & Group 1(CC) & Group 2(CT) & Group 3(TC) & Group 4(TT) \\
\hline WBC & $9.07 \pm 1.68$ & $10.70 \pm 1.78$ & $10.00 \pm 0.70$ & $10.13 \pm 0.54$ \\
\hline LYM & $3.93 \pm .34$ & $3.78 \pm 0.44$ & $3.95 \pm 0.35$ & $4.88 \pm 0.31$ \\
\hline MONO & $0.80 \pm 0.15$ & $0.83 \pm 0.17$ & $0.90 \pm 0.10$ & $0.95 \pm 0.03$ \\
\hline NUET & $2.73 \pm 0.94$ & $4.28 \pm 0.85$ & $3.00 \pm 1.00$ & $2.13 \pm 0.13$ \\
\hline EOS & $1.60 \pm 0.25$ & $1.83 \pm 0.59$ & $2.15 \pm 0.15$ & $2.18 \pm 0.32$ \\
\hline LYM \% & $45.10 \pm 3.65$ & $37.48 \pm 4.61$ & $40.35 \pm 6.65$ & $48.38 \pm 2.49$ \\
\hline MONO \% & $8.30 \pm 0.26$ & $7.00 \pm 0.64$ & $8.50 \pm 1.20$ & $9.15 \pm 0.49$ \\
\hline NUET \% & $29.20^{\mathrm{ab}} \pm 4.05$ & $39.98^{\mathrm{a}} \pm 3.22$ & $29.40^{\mathrm{ab}} \pm 7.80$ & $21.40^{b} \pm 0.58$ \\
\hline EOS \% & $17.40 \pm 0.15$ & $15.55 \pm 3.32$ & $21.75 \pm 0.05$ & $21.08 \pm 2.10$ \\
\hline HGB & $11.63 \pm 0.82$ & $12.75 \pm 1.04$ & $11.90 \pm 0.40$ & $11.80 \pm 0.35$ \\
\hline HCT & $34.80 \pm 1.64$ & $37.25 \pm 2.70$ & $36.05 \pm 0.45$ & $35.75 \pm 0.77$ \\
\hline $\mathrm{RBC}$ & $10.26 \pm 0.92$ & $11.41 \pm 0.83$ & $10.11 \pm 0.90$ & $10.02 \pm 0.35$ \\
\hline $\mathrm{MCV}$ & $34.20 \pm 1.72$ & $32.63 \pm 0.70$ & $35.85 \pm 2.75$ & $35.73 \pm 0.59$ \\
\hline $\mathrm{MCH}$ & $11.33 \pm 0.23$ & $11.15 \pm 0.27$ & $11.80 \pm 0.70$ & $11.80 \pm 0.14$ \\
\hline $\mathrm{MCHC}$ & $33.30 \pm 1.01$ & $34.23 \pm 0.40$ & $33.10 \pm 0.60$ & $33.05 \pm 0.26$ \\
\hline RDW & $22.50 \pm 0.31$ & $23.30 \pm 0.45$ & $22.45 \pm 1.55$ & $22.80 \pm 0.62$ \\
\hline RDWA & $20.83 \pm 0.85$ & $20.48 \pm 0.41$ & $22.10 \pm 0.80$ & $22.23 \pm 0.53$ \\
\hline PLT & $539.33 \pm 83.48$ & $278.50 \pm 86.72$ & $534.50 \pm 75.50$ & $521.25 \pm 52.06$ \\
\hline MPV & $4.77^{\mathrm{ab}} \pm 0.07$ & $4.98^{\mathrm{ab}} \pm 0.21$ & $4.40^{b} \pm 0.20$ & $5.15^{\mathrm{a}} \pm 0.18$ \\
\hline
\end{tabular}

$a, b$ : Means within a row containing different superscript tended to differ $(p<0.05)$; : SEM $=$ Standard Error of the Mean.CC: Control animals, CT : Ewes untreated while offspring treated with 10.000IU of vitamin A. TC : Ewes treated with $15.000 \mathrm{IU}$ vitamin A with offspring not treated. TT : Ewes and their offspring were treated with vitamin A . 
Website: www.aun.edu.eg/faculty_agriculture/journals_issues_form.php E-mail:ajas@aun.edu.eg

Table 6. Concentrations of blood profiles of lambs supplemented Vitamin A.

\begin{tabular}{|c|c|c|c|c|}
\hline $\begin{array}{ll}\text { Groups } & \text { Items } \\
\end{array}$ & Group 1(CC) & Group 2(CT) & Group 3(TC) & Group 4(TT) \\
\hline WBC & $18.90 \pm 3.70$ & $13.77 \pm 2.96$ & $14.40 \pm 1.56$ & $12.87 \pm 1.68$ \\
\hline LYM & $9.85 \pm 1.15$ & $8.07 \pm 2.72$ & $10.10 \pm 0.90$ & $8.10 \pm 1.14$ \\
\hline MONO & $1.90 \pm 0.70$ & $1.23 \pm 0.18$ & $1.07 \pm 0.19$ & $1.13 \pm 0.22$ \\
\hline NEUT & $6.00^{\mathrm{a}} \pm 2.10$ & $3.33^{\mathrm{ab}} \pm 0.88$ & $1.97^{b} \pm 0.90$ & $2.80^{\mathrm{ab}} \pm 0.72$ \\
\hline EOS & $1.15 \pm 0.25$ & $1.13 \pm 0.38$ & $1.27 \pm 0.28$ & $0.83 \pm 0.35$ \\
\hline LYM \% & $53.00 \pm 4.00$ & $56.57 \pm 7.52$ & $71.40 \pm 6.75$ & $63.00 \pm 1.95$ \\
\hline MONO \% & $9.45 \pm 1.45$ & $8.97 \pm 0.69$ & $7.03 \pm 0.65$ & $8.37 \pm 0.59$ \\
\hline NUET \% & $30.75 \pm 5.15$ & $26.80 \pm 7.75$ & $13.50 \pm 5.30$ & $21.37 \pm 3.10$ \\
\hline EOS \% & $6.80 \pm 2.60$ & $7.67 \pm 0.90$ & $8.07 \pm 1.39$ & $7.27 \pm 3.96$ \\
\hline HGB & $10.75 \pm 2.15$ & $8.15 \pm 2.08$ & $8.30 \pm 0.30$ & $8.80 \pm 1.32$ \\
\hline HCT & $23.85 \pm 0.05$ & $22.73 \pm 3.38$ & $23.23 \pm 0.30$ & $25.07 \pm 3.95$ \\
\hline $\mathrm{RBC}$ & $11.53 \pm 1.68$ & $8.92 \pm 1.11$ & $8.44 \pm 0.27$ & $8.68 \pm 1.61$ \\
\hline $\mathrm{MCV}$ & $24.90 \pm 0.70$ & $25.33 \pm 0.62$ & $20.87 \pm 7.18$ & $28.60 \pm 1.35$ \\
\hline $\mathrm{MCH}$ & $9.25 \pm 0.55$ & $9.10 \pm 0.30$ & $9.80 \pm 0.00$ & $10.10 \pm 0.25$ \\
\hline $\mathrm{MCHC}$ & $37.15 \pm 1.05$ & $35.70 \pm 0.20$ & $35.67 \pm 0.83$ & $35.43 \pm 1.27$ \\
\hline RDW & $30.25 \pm 1.55$ & $29.77 \pm 1.19$ & $27.53 \pm 1.47$ & $26.40 \pm 1.31$ \\
\hline RDWA & $17.60 \pm 0.10$ & $16.47 \pm 0.96$ & $18.17 \pm 0.71$ & $18.23 \pm 0.38$ \\
\hline PLT & $732.50 \pm 49.50$ & $693.33 \pm 62.84$ & $585.33 \pm 216.15$ & $982.33 \pm 46.81$ \\
\hline MPV & $4.25 \pm 0.05$ & $4.20 \pm 0.10$ & $3.87 \pm 0.18$ & $4.40 \pm 0.21$ \\
\hline
\end{tabular}

a, b: Means within a row containing different superscript tended to differ $(\mathrm{p}<0.05)$; $\mathrm{c}$ : SEM $=$ Standard Error of the Mean.CC: Control animals, CT : Ewes untreated while offspring treated with 10.000IU of vitamin A. TC : Ewes treated with 15.000 IU vitamin A with offspring not treated. TT : Ewes and their offspring were treated with vitamin A .

\subsection{Blood serum metabolites of ewes and their offspring:}

As show in Table 7, concentrations of total protein and globulin were higher $(p<0.05)$ in blood serum of untreated ewes (group I), while albumin /globulin ratio were higher $(p<0.05)$ in group IV, but level of albumin reduced $(\mathrm{P}<0.05)$ in blood serum of group III compared with other groups. Concentration of total cholesterol increased $(p<0.05)$ in blood serum of group IV compared with other ones. Concentrations of glucose, triglycerides and urea in blood serum were not different $(\mathrm{P}>0.05)$ among treatments.

Concentrations of blood metabolites in offspring as affected by supplementation of vitamin A represented in Table 8. Data revealed that levels of total protein increased $(p<0.05)$ in treated groups compared with control one. Concentrations of albumin, globulin, glucose, triglyc- erides and urea did not differ due to supplemented animals with Vitamin A. In the same field, total cholesterol concentration was higher $(\mathrm{P}<0.05)$ in blood serum of control group while the lowest level was observed in blood serum of group 4. Creatinine concentration increased $(\mathrm{P}<0.05)$ in blood serum of treated lambs compared with the control ones. Similar results were reported in goats injected with 50,000 IU of vitamin A twice a week for four weeks before kidding (Abd Eldaim et al., 2015). It is well established that vitamin A plays a role in the expression of genes and proteins involved in cellular metabolism (Smith and Akinbamijo, 2000). Hashem et al. (2016) found in blood of Rahmani ewes that Vitamin A treatment increased significantly $(\mathrm{P}<0.05)$ total protein and globulin $(\mathrm{P}<0.01)$ concentrations than other groups. 
Table 7. Concentrations of blood metabolites of ewes upplemented vitamin A.

\begin{tabular}{|l|c|c|c|c|}
\hline Groups Items & Group 1(CC) & Group 2(CT) & Group 3(TC) & Group 4(TT) \\
\hline Total protein $(\mathrm{g} / \mathrm{dl})$ & $8.58^{\mathrm{a}} \pm 0.42$ & $7.00^{\mathrm{b}} \pm 0.12$ & $7.12^{\mathrm{b}} \pm 0.28$ & $7.00 \pm 0.19$ \\
\hline Albumin $(\mathrm{g} / \mathrm{dl})$ & $4.67^{\mathrm{a}} \pm 0.18$ & $4.74^{\mathrm{a}} \pm 0.18$ & $3.97^{\mathrm{b}} \pm 0.15$ & $4.57^{\mathrm{a}} \pm 0.18$ \\
\hline Globulin $(\mathrm{g} / \mathrm{dl})$ & $3.92^{\mathrm{a}} \pm 0.52$ & $2.26^{\mathrm{b}} \pm 0.22$ & $3.15^{\mathrm{b}} \pm 0.24$ & $2.43^{\mathrm{bc}} \pm 0.14$ \\
\hline A/G ratio & $1.32^{\mathrm{b}} \pm 0.19$ & $1.97^{\mathrm{a}} \pm 0.67$ & $1.37^{\mathrm{b}} \pm 0.11$ & $2.03^{\mathrm{a}} \pm 0.20$ \\
\hline Total cholesterol $(\mathrm{mg} / \mathrm{dl})$ & $103.9^{\mathrm{b}} \pm 13.70$ & $137.6^{\mathrm{ab}} \pm 13.75$ & $105.4^{\mathrm{b}} \pm 8.82$ & $147.8^{\mathrm{a}} \pm 20.92$ \\
\hline Glucose $(\mathrm{mg} / \mathrm{dl})$ & $60.88 \pm 7.53$ & $45.30 \pm 5.96$ & $34.55 \pm 2.93$ & $43.85 \pm 3.45$ \\
\hline Triglycerides $(\mathrm{mg} / \mathrm{dl})$ & $44.79 \pm 6.99$ & $69.80 \pm 14.78$ & $39.90 \pm 5.60$ & $45.76 \pm 9.08$ \\
\hline Urea $(\mathrm{mg} / \mathrm{dl})$ & $53.53 \pm 10.11$ & $39.91 \pm 7.34$ & $38.48 \pm 5.10$ & $39.61 \pm 5.58$ \\
\hline Creatinine $(\mathrm{mg} / \mathrm{dl})$ & $0.83 \pm 0.06$ & $0.79 \pm 0.09$ & $0.87 \pm 0.05$ & $0.90 \pm 0.03$ \\
\hline
\end{tabular}

a, b: Means within a row containing different superscript tended to differ ( $\mathrm{p}<0.05$ ); $\mathrm{c}$ : SEM $=$ Standard Error of the Mean.CC: Control animals, CT : Ewes untreated while offspring treated with 10.000IU of vitamin A. TC : Ewes treated with 15.000 IU vitamin A with offspring not treated. TT : Ewes and their offspring were treated with vitamin A .

Table 7. Concentrations of blood metabolites of lambs supplemented vitamin A.

\begin{tabular}{|l|c|c|c|c|}
\hline Groups Items & Group 1(CC) & Group 2(CT) & Group 3(TC) & Group 4(TT) \\
\hline Total protein (g/dl ) & $6.50^{\mathrm{b}} \pm 0.85$ & $7.27^{\mathrm{a}} \pm 0.28$ & $7.27^{\mathrm{a}} \pm 0.35$ & $7.02 \mathrm{a} \pm 0.26$ \\
\hline Albumin (g/dl ) & $3.82 \pm 0.62$ & $4.13 \pm 0.25$ & $4.29 \pm 0.25$ & $3.97 \pm 0.21$ \\
\hline Globulin (g/dl ) & $1.79 \pm 2.27$ & $3.14 \pm 0.24$ & $2.98 \pm 0.26$ & $3.05 \pm 0.26$ \\
\hline A/G ratio & $1.21^{\mathrm{b}} \pm 0.01$ & $1.45^{\mathrm{b}} \pm 0.17$ & $1.64^{\mathrm{a}} \pm 0.17$ & $1.60^{\mathrm{a}} \pm 0.26$ \\
\hline Total cholesterol (mg/dl ) & $153.56^{\mathrm{a}} \pm 8.47$ & $112.82^{\mathrm{b}} \pm 14.59$ & $119.83^{\mathrm{ab}} \pm 11.91$ & $104.05^{\mathrm{b}} \pm 10.24$ \\
\hline Glucose (mg/dl ) & $58.3 \pm 2.15$ & $70.48 \pm 7.33$ & $72.73 \pm 4.89$ & $65.90 \pm 2.37$ \\
\hline Triglycerides (mg/dl)1 & $91.86 \pm 18.89$ & $110.54 \pm 23.56$ & $98.41 \pm 22.88$ & $66.36 \pm 10.23$ \\
\hline Urea(mg/dl ) & $36.8 \pm 46.51$ & $22.16 \pm 20.55$ & $30.43 \pm 18.13$ & $25.18 \pm 15.81$ \\
\hline Creatinine (mg/dl ) & $0.82^{\mathrm{b}} \pm 0.07$ & $1.10^{\mathrm{a}} \pm 0.07$ & $1.08^{\mathrm{a}} \pm 0.03$ & $1.11^{\mathrm{a}} \pm 0.09$ \\
\hline
\end{tabular}

$a$, b: Means within a row containing different superscript tended to differ $(\mathrm{p}<0.05)$; : SEM $=$ Standard Error of the Mean.CC: Control animals, CT : Ewes untreated while offspring treated with 10.000IU of vitamin A. TC : Ewes treated with 15.000 IU vitamin A with offspring not treated. TT : Ewes and their offspring were treated with vitamin A

In addition, vitamin $\mathrm{A}$ has been shown to regulate the expression of immunoglobulin and myeloid cell differentiation (Pletsityi and Askerov, 1982), and enhance B-lymphocyte proliferation in pregnant dairy cows (De et al., 2014). Previous in vivo and in vitro studies indicated that retinoic acid, the active form of vitamin A, may promote antibody production and immune cell maturation (Ross, 2012).

In conclusion, addition vitamin $\mathrm{A}$ improved body performance of ewes and their offspring without any harmful effect on blood constituents.

\section{References}

Abd Eldaim, M.A., Gaafar, K.M., Darwish, R.A., Mahboub, H.D., Helal, M.A., 2015. Prepartum vitamin A supplementation enhances goat doe health status and kid viability and performance. Small Rumin. Res. 129, 6-10.

Alosilla, C.E. Jr., L.R. McDowell, N.S. Wilkinson, C.R. Staples and W.W. Thatcher et al., 2007. Bioavailability of vitamin A sources for cattle. J. Anim. Sci., 85: 1235-1238.

Arana, A., J.A. Mendizabal, M. Alzon, B. Soret and A. Purroy, 2008. The 
effect of vitamin A supplementation on postnatal adipose tissue development of lambs. J. Anim. Sci., 86: 3393-3400.

Bendich, A. and S.S. Shapiro, 1986. Effect of $\beta$-carotene and canthaxanthin on the immune responses of the rat. J. Nutr. 116: 2254.

Bendich, A., 1993. Physiological role of antioxidants in the immune system. J. Dairy Sci., 76: 2789-2794.

Carrillo-Lopez, A., E. M. Yahia, G. K. Ramirez-Padilla, 2010. Bioconversion of Carotenoids in Five Fruitsand Vegetables to Vitamin A Measured by Retinol Accumulation in Rat Livers. Am. J. of Agric. Biolol. Sci., 5: 215-221.

Chew, B.P., 1996. Importance of antioxidant vitamins in immunity and health in animals. Anim. Feed Sci. Tech., 59: 103-114.

De, K., Pal, S., Prasad, S., Dang, A.K., 2014. Effect of micronutrient supplementationon the immune function of crossbred dairy cows under semi-arid tropicalenvironment. Trop. Anim. Health Prod. 46, 203211.

Grimble, R.F., 2001. Nutritional modulation of immune function. Proc. Nutr. Soc., 60: 389-397.

Hashem, N.M., D. Abd-Elrazek, Z.R. Abo-Elezz, M.G.A. Latif, 2016. Effect of vitamin $\mathrm{A}$ or $\mathrm{C}$ on physiological and reproductive response of Rahmani ewes during subtropical summer breeding season. Small Ruminant Research 144 (2016) 313-319

Kamiloglu, N.N., Beytut, E., Güven, A., Altinsaat, C., 2006. Changes in theerythrocyte anti-oxidant system of offspring of dams treated with Vitamin A and carotene during gestation. Small Rumin. Res. 65, 142-148.

Lin, H., L.F. Wang, J.L. Song, Y.M. Xie and Q.M. Yang, 2002. Effect of dietary supplemental levelsof vitamin A on the egg production and immune responses of heat-stressed laying hens.Poul.Sci.,81: 458- 465.

Marai, I.F.M., El- Darawany, A.A., Fadiel, A., Abdel-Hafez, M.A.M., 2008. Reproductive performance traits as affected by heat stress and its alleviation insheep. Trop. Subtrop. Agroecosyst. 8, 209-234.

May, B.J., 1982. The Minimum vitamin A requirement for growing and finishing lambs. M.S. Thesis, Angel State Univ., S. Angel Tex, USA.

Meacham, T.N., K.P. Bovard, B.M. Priode and J.P. Fontenot, 1970. Effect of supplemental vitamin Aon the performance of beef cows and their calves. J. Anim. Sci., 31: 428433.

Oka, A., Y. Maruo, T. Miki, T. Yamasaki and T. Saito, 1998. Influence of vitamin A on the quality of beef from the Tajima strain of Japanese Black cattle. Meat Sci., 48: 159167.

Pletsityi, K.D., Askerov, M.A., 1982. Effect of vitamin A on immunogenesis. Vopr.Pitan1, 38-40.

Pope, A.L., P.H. Phillips and G. Bohstedt, 1949. Vitamin A and C concentrations in the blood plasma of ewes, their milk and in the blood plasma of their lambs. J. Anim. Sci., 8: 57-66.

Rode, L.M., T.A. Mc Allister and K.J. Cheng, 1990. Microbial degradation of vitamin $\mathrm{A}$ in rumen fluid of steers fed concentration, hay, or straw diets. Can. J. Anim. Sci., 70: 227-233.

Ross, A.C., 2012. Vitamin A and retinoic acid in $\mathrm{T}$ cell-related immunity. Am. J. Clin.Nutr. 96, 1166S$1172 \mathrm{~S}$.

SAS, 2000. Users Guide. Release 8.1 ed. SAS Institute Inc., Cary, NC. 
Smith, O.B., and O.O., Akinbamijo, 2000. Micronutrients and reproduction in farmanimals. Anim. Reprod. Sci. 60, 549-560.

Sporn, M.B., A.B., Roberts and D.S., Goodman, 1994. In The Retinoids, $2^{\text {nd }}$ edn.RavenPress, New York.

Swanson, E.W., G.G. Martin, F.E. Pardue and G.M. Gorman, 1986. Milk production of cows fed diets deficient in vitamin A. J. Anim. Sci., 27: 541-548.

Vander Peet-Schwering, C.M.C., A.J.M. Jansman, H. Smidt and I. Yoon, 2007. Effects of yeast culture on performance, gut integrity and blood cell composition of weanling pigs. J. Anim. Sci., 85: 3099-3109.

West, J.W., 1997. Nutritional strategies for managing the heat-stressed dairy cow. J. Anim. Sci. 77, 21-35.

Yang, W., Ping Wang, Yuanqiang Jing, Zaibin Yang, Chongyu Zhang, Shuzhen Jiang and Guiguo Zhang 2010. Effects of Vitamin A on Growth Performance, Antioxidant Status and Blood Constituents in Lactating Grey Goat American Journal of Animal and Veterinary Sciences 5 (4): 274-281, 2010. 
تأثير إضافة فيتامين أ على أداء و مكونات دم النعاج الصعيدى ومواليدها ابر اهيم عبد الله سليمان، محمد نصرت محمود عبد العاطى، جمال بلرى ابو الوفا محمود وزينب محمد محمد

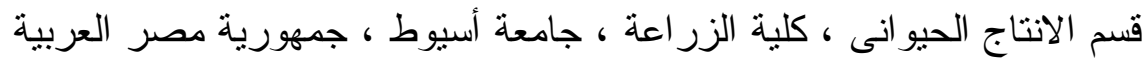

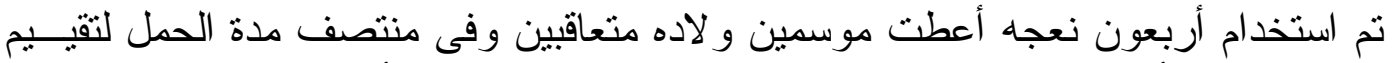

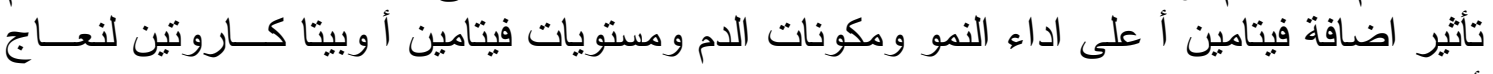

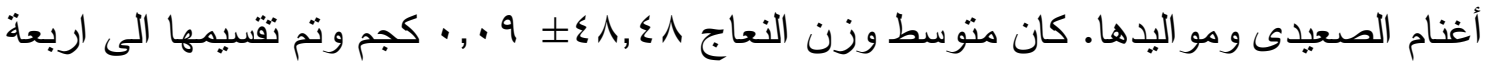

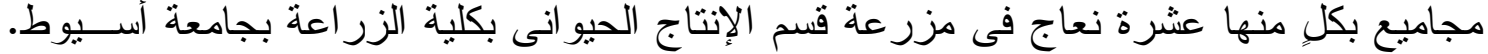

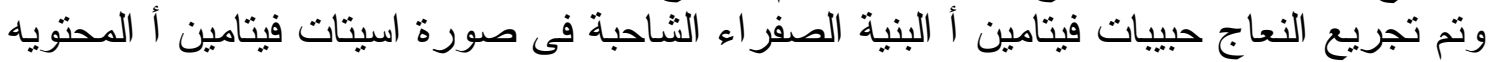

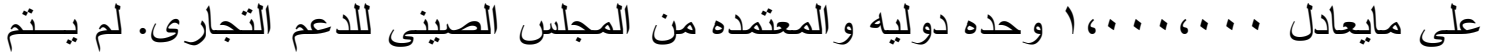

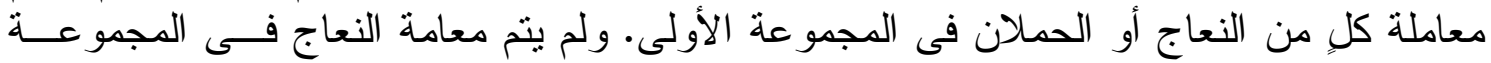

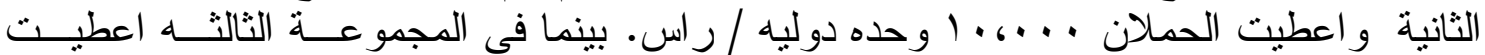

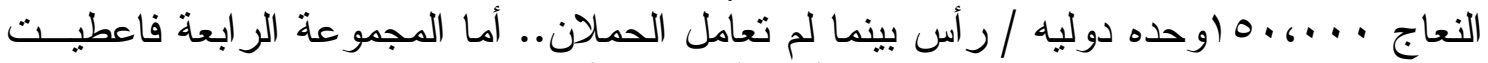

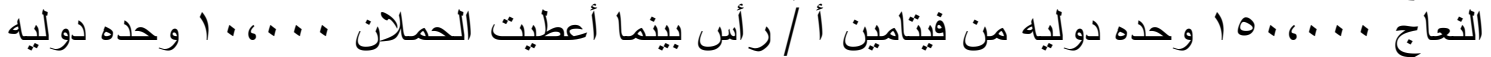

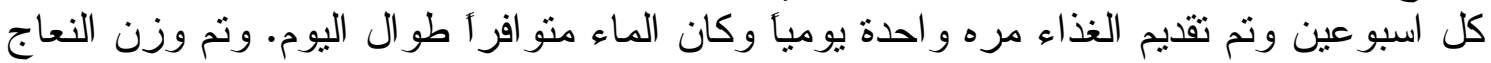

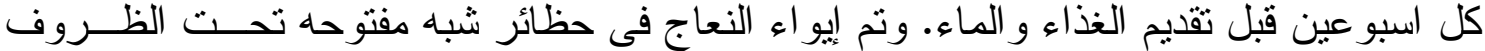

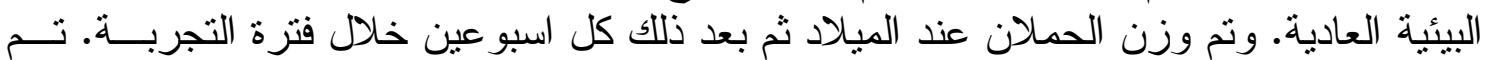

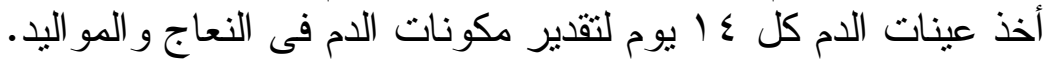

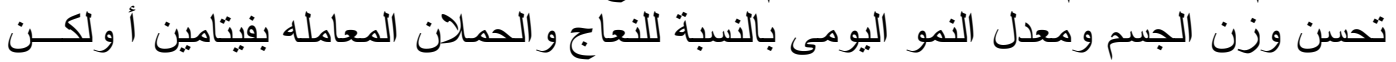

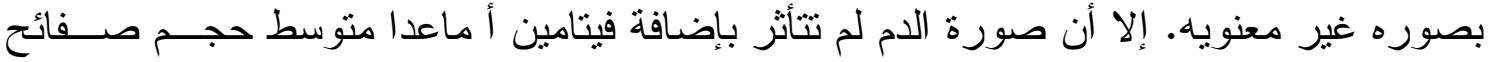

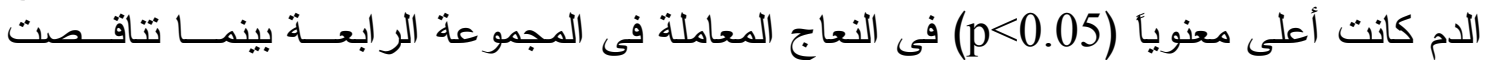

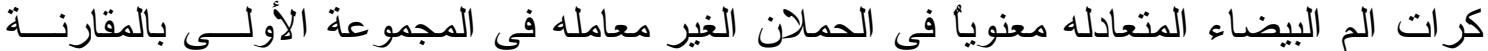

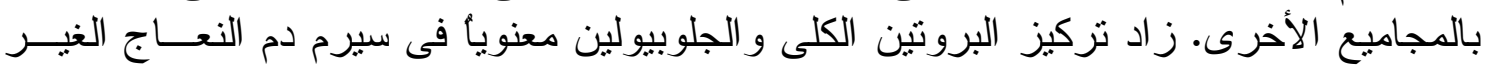

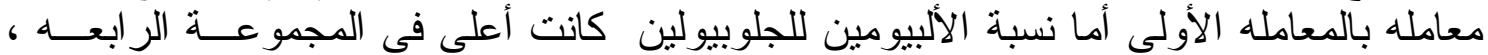

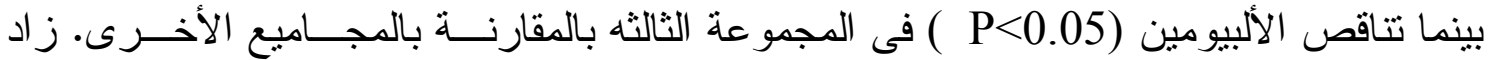

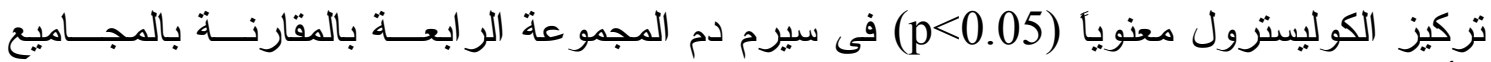

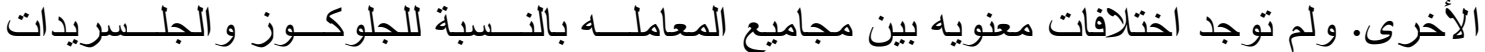

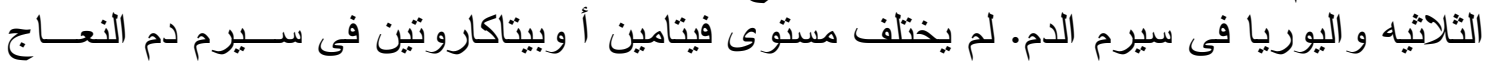

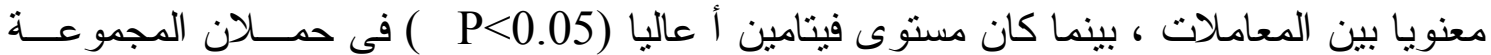

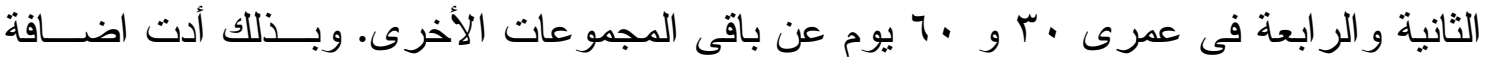

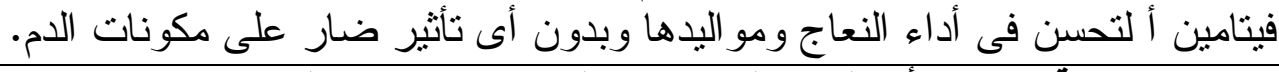

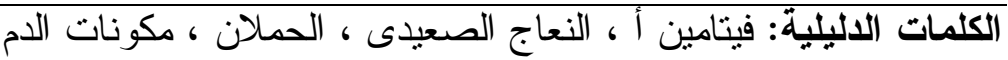


Animals were fed roughage and concentrate diet ad libitum during the experimental period. The concentrate diet was consisted of $34 \%$ yellow corn, $38 \%$ wheat bran, $25 \%$ decorticated cotton seeds $2 \%$ limestone and $1 \%$ sodium chloride.

Item diet

Organic matter $\quad 91.85$

Crude Protein $\quad 15.60$

Ether extract $\quad 4.18$

Crude Fiber $\quad 8.73$

Nitrogen Free Extract $\quad 61.54$

$\begin{array}{ll}\text { Ash } & 9.95\end{array}$ 